\title{
Morphology and distribution of the South American snake Chironius leucometapus (Serpentes: Colubridae)
}

\author{
Omar Torres-Carvajal, ${ }^{1}$ Claudia Koch, ${ }^{2}$ Jorge H. Valencia, ${ }^{3}$ Pablo J. Venegas, ${ }^{4}$ and Lourdes Y. \\ Echevarría ${ }^{5}$ \\ ${ }^{1}$ Museo de Zoología, Escuela de Ciencias Biológicas, Pontificia Universidad Católica del Ecuador. Avenida 12 de Octubre y \\ Roca, Apartado 17-01-2184, Quito, Ecuador. E-mail: omartorcar@gmail.com. \\ ${ }^{2}$ Department of Herpetology, Zoologisches Forschungsmuseum Alexander Koenig (ZFMK). Adenauerallee 160, 53113 Bonn, \\ Germany. E-mail: C.Koch@leibniz-zfmk.de. \\ ${ }^{3}$ Laboratorio de Anfibios y Reptiles, Fundación Herpetológica Gustavo Orcés. Av. Amazonas N34-12 y Rumipamba, Casilla \\ 17-03-448, Quito, Ecuador. E-mail: jorgehvalenciav@yahoo.com. \\ ${ }^{4}$ División de Herpetología-Centro de Ornitología y Biodiversidad (CORBIDI). Santa Rita No. 105 Of. 202, Urb. Huertos de \\ San Antonio, Surco, Lima, Perú. E-mail: sancarranca@yahoo.es. \\ ${ }_{5}^{5}$ Pontifícia Universidade Católica do Rio Grande do Sul (PUCRS), Laboratório de Sistemática de Vertebrados. Av. Ipiranga \\ 6681, Porto Alegre, RS 90619-900, Brazil. E-mail: lourdese.20@gmail.com.
}

\begin{abstract}
Morphology and distribution of the South American snake Chironius leucometapus (Serpentes: Colubridae). Chironius leucometapus was described more than 25 years ago as subspecies of $C$. fuscus from restricted area in the Department of Junín in central Peru, with no additional specimens reported since. Examination of 17 new specimens reveals that $C$. leucometapus is widespread along the Amazonian slopes of the Andes between central Peru and northern Ecuador. New morphological data including scalation, hemipenes, color in life, and the first description of the skull of Chironius to be based on high-quality CT-scan images are presented. The number of species of Chironius from Ecuador is elevated to eight.
\end{abstract}

Keywords: Andes, CT-scanning, hemipenis, skull, Squamata.

\begin{abstract}
Resumen
Morfología y distribución de la serpiente sudamericana Chironius leucometapus (Serpentes: Colubridae). Chironius leucometapus fue descrita hace 25 años como una subespecie de $C$. fuscus en un área restringida del Departamento de Junín en el centro de Perú, sin que se hayan reportado más especímenes desde entonces. Datos de 17 especímenes nuevos revelan que $C$. leucometapus es una especie de amplia distribución a lo largo de las estribaciones amazónicas de los Andes entre Perú central y el norte de Ecuador. Se presentan datos morfológicos nuevos, que incluyen escamación, hemipenes, color en vida, y la primera descripción del cráneo de una especie de Chironius basada en imágenes de alta calidad de escaneados CT. El número de especies de Chironius en Ecuador es elevado a ocho.
\end{abstract}

Received 01 August 2019

Accepted 15 September 2019

Distributed December 2019 
Palabras clave: Andes, hemipenes, cráneo, Squamata, tomografía computarizada.

\begin{abstract}
Resumo
Morfologia e distribuição da serpente sul-americana Chironius leucometapus (Serpentes: Colubridae). Chironius leucometapus foi descrita há 25 anos como uma subespécie de $C$. fuscus em uma área restrita do Departamento de Junín, no centro do Peru, sem mais espécimes relatados desde então. Dados de 17 novos espécimes revelam que $C$. leucometapus é uma espécie de ampla distribuição ao longo do sopé amazônico dos Andes, entre o centro do Peru e o norte do Equador. Novos dados morfológicos são apresentados, incluindo descamação, hemipênis, coloração em vida e a primeira descrição do crânio de uma espécie de Chironius com base em imagens de alta qualidade de tomografias computadorizadas. Elevamos para oito o número de espécies de Chironius para o Equador.
\end{abstract}

Palavras-chave: Andes, crânio, hemipênis, Squamata, tomografia computadorizada.

\section{Introduction}

Traditionally ranked as genus, Chironius Fitzinger, 1826 is nested within the snake clade Colubridae and contains 22 recognized species occurring from Central America (Honduras) south to Uruguay and northeastern Argentina (Bailey 1955, Dixon et al. 1993, Hollis 2006, Klaczko et al. 2014, Hamdan et al. 2017). Also known as sipo snakes, species of Chironius are large, diurnal, terrestrial or arboreal, with long tail and big eyes, and differ from other Neotropical snakes in having 10 or 12 dorsal scale rows at midbody (Dixon et al. 1993).

An extensive taxonomic revision of Chironius was presented by Dixon et al. (1993), who recognized 13 species and 11 subspecies. Later, Hollis (2006) recognized 20 species after elevating all subspecies of Dixon et al. (1993) to full species status. Subsequently, two additional species of Chironius were described from Brazil (Fernandes and Hamdan 2014, Hamdan and Fernandes 2015). Although the monophyly was questioned recently in a phylogenetic analysis of Squamata (Pyron et al. 2013), the monophyletic status of Chironius is supported by most studies based on morphological and/or molecular evidence (Hollis 2006, Klaczko et al. 2014, Figueroa et al. 2016, Hamdan et al. 2017, Torres-Carvajal et al. 2019), including recent large-scale molecular phylogeny of caenophidian snakes (Zaher et al. 2019). Based on comprehensive phylogenetic analysis including $\sim 90 \%$ of all species of sipo snakes, TorresCarvajal et al. (2019) recognized 14 clades within widespread species $C$. exoletus (Linnaeus, 1758), C. fuscus (Linnaeus, 1758), C. monticola Roze, 1952, and C. multiventris Schmidt and Walker, 1943 as putative undescribed species, suggesting that the diversity of Chironius may be greater than currently recognized.

The western Amazon Basin is one of the most biodiverse areas of the planet (Ter Steege et al. 2003, Erwin et al. 2004, Roll et al. 2017). Importantly, it still maintains significant areas of tropical moist forest and has high probability of stable climatic conditions despite global warming (Killeen et al. 2007). Currently, seven species of Chironius are known from western Amazonia in Ecuador and Peru, as follow: C. carinatus (Linnaeus, 1758), C. exoletus, C. fuscus, $C$. leucometapus Dixon, Wiest, and Cei, 1993, C. monticola, C. multiventris, and C. scurrulus (Wagler, 1824). Of these, C. carinatus and $C$. leucometapus have not been recorded from Ecuador. The latter was described based on 16 preserved specimens from Chanchamayo (type locality) in the Peruvian Department of Junín and surroundings, with no additional specimens reported since. This species differs from all other 
known congeners except $C$. fuscus in having 10 dorsal scale rows at midbody, an entire anal plate, lightly colored lower portion of supralabials, and keeled paravertebral rows. Preserved specimens of C. leucometapus have white, yellow, or brown snout and forehead, and lack postocular stripe, whereas $C$. fuscus has uniformly colored head and postocular stripe (Dixon et al., 1993). In addition, C. leucometapus differs from $C$. fuscus in lacking enlarged spines on the proximal end of the spinous portion of the hemipenial body. Here we report and describe additional specimens of Peruvian and Ecuadorian C. leucometapus that significantly increase the distributional range of the species.

\section{Materials and Methods}

All specimens of Chironius leucometapus from Ecuador $(N=9)$ are in Ecuadorian herpetological collections at Museo de Zoología, Pontificia Universidad Católica del Ecuador (QCAZ); División de Herpetología del Instituto Nacional de Biodiversidad (DHMECN); Museo de Historia Natural Gustavo Orcés, Escuela Politécnica Nacional (EPN); and Laboratorio de Anfibios y Reptiles, Fundación Herpetológica Gustavo Orcés (FHGO). Specimens of $C$. leucometapus from Peru $(N=8)$ are in Centro de Ornitología y Biodiversidad (CORBIDI) in Lima, Perú (Appendix I). Additional data for $C$. leucometapus and its sister species C. fuscus (Torres-Carvajal et al. 2019) were taken from the literature (Dixon et al. 1993). Snout-vent length (SVL) and tail length (TL) measurements were recorded to the nearest $0.1 \mathrm{~cm}$ with tape measure. All other measurements were made with digital calipers and recorded to the nearest $0.01 \mathrm{~mm}$. Sex was determined by noting the presence of hemipenes, everted or by tail dissection. Hemipenes of $C$. leucometapus (FHGO 3570, left) and C. fuscus (FHGO 11478, left) were prepared following standard techniques (Manzani and Abe 1988, Pesantes 1994, Zaher 1999). Terminology for hemipenial description follows that of Dixon et al. (1993).
To study the skull of Chironius leucometapus, the head of one specimen (QCAZ 10977) was $\mathrm{X}$-rayed in 3D with high-resolution micro-CT scanner (Bruker SkyScan 1173) at The University of Toronto, Canada. This specimen was CTscanned in $180^{\circ}$ degrees at rotation steps of $0.2^{\circ}$ with tube voltage of $47 \mathrm{kV}$ and tube current of $170 \mathrm{uA}$, without the use of filter, at an image resolution of $18.15 \mu \mathrm{m}$. Scan duration was $38: 31$ min with an exposure time of $950 \mathrm{~ms}$. The CTdataset was reconstructed using N-Recon software version 1.7.1.6 (Bruker MicroCT) and rendered in three dimensions through the aid of CTVox 2.6 for Windows 64 bits (Bruker MicroCT). Terminology for skull structures follows Bullock and Tanner (1966), Cundall and Irish (2008), and Hamdan and Fernandes (2015).

Interspecific, uncorrected p-distances were calculated for the mitochondrial ND4 gene in PAUP*4.0a-build 165 (Swofford 2002), using the data matrix generated by Torres-Carvajal et al. (2019).

\section{Results}

Here we present the first records of Chironius leucometapus from Ecuador, as well as new records from Peru (Figure 1). Based on examination of 17 specimens, we provide novel data on external morphology, osteology, hemipenial morphology, coloration in life, distribution and natural history.

\section{Morphological and Genetic Variation}

A comparison of scalation and measurements between the populations of Chironius leucometapus from Ecuador and Peru is presented in Table 1. In general, specimens from Ecuador and Peru are morphologically similar. Both males and females from Ecuador have more ventrals and fewer subcaudals than specimens from Peru. However, the only non-overlapping difference is the number of ventrals. Aside from morphological similarity, the ND4 uncorrected genetic distance between the sample of Chironius leucometapus 


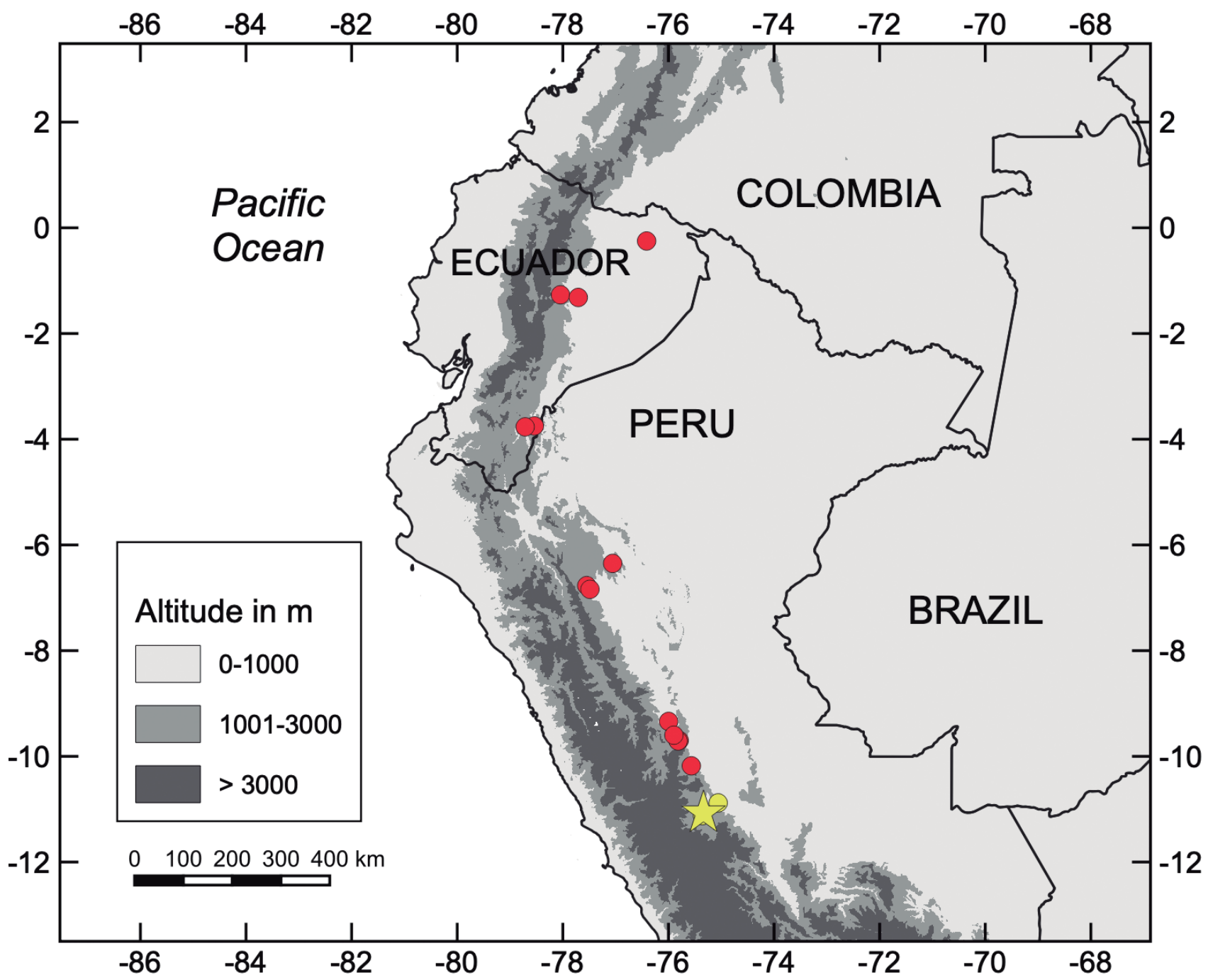

Figure 1. Distribution of Chironius leucometapus in Ecuador and Peru. Yellow symbols (star: type locality) correspond to localities reported by Dixon et al. (1993); red symbols are localities reported in this paper.

from Peru and the sample from Ecuador is 0.065. Distances for this gene range between 0.090 (C. multiventris/C. exoletus) and 0.195 (C. multiventris/C. scurrulus) among sampled species of Chironius (Torres-Carvajal et al. 2019).

\section{Skull (QCAZ 10977; Figures 2 and 3)}

Snout.-Premaxilla subtriangular in frontal view, with posterodorsally oriented ascending process approaching, but not in contact with, anterior end of nasals; premaxillary transverse processes similar in length to ascending process, extending posterolaterally to point anterior to maxillae; vomerine processes short, posterolaterally oriented, ventrally overlapping but not in contact with anterior end of vomers. Septomaxillae strongly convex dorsomedially, each with short, broad ascending conchal process freely extending anterolaterally beyond lateral margins of nasals; slightly separated from each other; approaching, but not in contact with frontals posteriorly; connected to vomers 
Table 1. Scale counts and measurements of populations of Chironius leucometapus from Ecuador and Peru. Range (first line) and mean \pm SD (second line) are presented when appropriate. Sample size is presented in parentheses if different from that in heading.

\begin{tabular}{|c|c|c|c|}
\hline Character & $\begin{array}{c}\text { Ecuador } \\
\text { (this study) } \\
\quad N=9\end{array}$ & $\begin{array}{c}\text { Peru } \\
\text { (this study) } \\
\quad \mathbf{N}=\mathbf{8}\end{array}$ & $\begin{array}{c}\text { C. leucometapus } \\
\text { (Dixon et al. 1993) } \\
\qquad N=16\end{array}$ \\
\hline $\begin{array}{l}\text { Longitudinal scale rows on } \\
\text { neck }\end{array}$ & 10 & 10 & 10 \\
\hline $\begin{array}{l}\text { Longitudinal scale rows at } \\
\text { midbody }\end{array}$ & 10 & 10 & 10 \\
\hline $\begin{array}{l}\text { Longitudinal scale rows } \\
\text { anterior to cloaca }\end{array}$ & $\begin{array}{l}10 \text { females } \\
8 \text { males }\end{array}$ & $\begin{array}{l}10 \text { females } \\
8 \text { males }\end{array}$ & $\begin{array}{l}10 \text { females } \\
8 \text { males }\end{array}$ \\
\hline Ventrals in males & $\begin{array}{c}156-159(N=4) \\
158 \pm 1.41\end{array}$ & $\begin{array}{c}147-150(N=3) \\
149 \pm 1.73\end{array}$ & $\begin{array}{c}151-153(N=5) \\
152.2 \pm 0.8\end{array}$ \\
\hline Ventrals in females & $\begin{array}{c}157-159(N=5) \\
158 \pm 0.71\end{array}$ & $\begin{array}{c}149-155(N=5) \\
152.6 \pm 2.61\end{array}$ & $\begin{array}{c}152-160(N=10) \\
155 \pm 2.5\end{array}$ \\
\hline Subcaudals in males & $\begin{array}{c}105-114(N=4) \\
110.5 \pm 4.04\end{array}$ & $\begin{array}{c}114-121(N=3) \\
118 \pm 3.61\end{array}$ & $\begin{array}{c}117-120(N=4) \\
118.5 \pm 1.3\end{array}$ \\
\hline Subcaudals in females & $\begin{array}{c}108-118(N=5) \\
112 \pm 4.24\end{array}$ & $\begin{array}{c}112-119(N=2) \\
115.5 \pm 4.95\end{array}$ & $\begin{array}{c}110-124(N=7) \\
117.4 \pm 5.00\end{array}$ \\
\hline Anals & 1 & 1 & 1 \\
\hline Anterior temporals & 1 & 1 & 1 \\
\hline Posterior temporals & $\begin{array}{c}0-1 \\
0.78 \pm 0.44\end{array}$ & 1 & 1 \\
\hline Preoculars & 1 & 1 & 1 \\
\hline Postoculars & 2 & $\begin{array}{c}2-3 \\
2.14 \pm 0.38\end{array}$ & 2 \\
\hline Supralabials & $\begin{array}{l}8-9(4,5,6) \\
8.87 \pm 0.35\end{array}$ & $\begin{array}{l}8-9(4,5,6) \\
8.87 \pm 0.35\end{array}$ & $9(4,5,6)$ \\
\hline Infralabials & $\begin{array}{c}8-10 \\
8.89 \pm 0.60\end{array}$ & $\begin{array}{c}8-9 \\
8.75 \pm 0.46\end{array}$ & $9-10$ \\
\hline Tail length/Total length & $\begin{array}{c}0.29-0.32 \\
0.31 \pm 0.01\end{array}$ & $\begin{array}{l}0.31-0.33(N=3) \\
0.32 \pm 0.01\end{array}$ & $0.31-0.34$ \\
\hline Maximum SVL (cm) & $\begin{array}{l}109.9 \text { females } \\
99.2 \text { males }\end{array}$ & $\begin{array}{c}80.10 \text { females } \\
-\end{array}$ & $\begin{array}{l}131.1 \text { females } \\
147.4 \text { males }\end{array}$ \\
\hline Maximum Total length $(\mathrm{cm})$ & $\begin{array}{l}155.9 \text { females } \\
142.4 \text { males }\end{array}$ & $\begin{array}{l}119.3 \text { females } \\
-\end{array}$ & $\begin{array}{l}174.3 \text { females } \\
195.0 \text { males }\end{array}$ \\
\hline
\end{tabular}


ventrally and posteromedially. Nasals in contact medially, each with tapered anterior process and broad, rounded lateral process; posterior processes of nasals approaching, but not in contact with anterior end of frontals; nasals in contact with posterior part of septomaxillae dorsomedially. Vomers with globular mesoventral portion and rounded exochoanal fenestra; in contact medially and almost in contact with anterior end of palatines laterally; large vertical posteromedial laminae of about one-third length of vomers, with large circular fenestra, in contact medially, but diverging dorsally and ventrally.

Braincase.-Prefrontals forming anterior margin of orbits; concave in posterior view; with broad, rounded anterior process in lateral view; in contact with frontals dorsally, maxillae ventrally, and choanal process of palatines ventromedially. Frontals paired, in close contact, with $\mathrm{V}$-shaped anterior margin medially, followed by straight medial suture posteriorly; forming anterodorsal margin of orbits; convex in dorsal view, with lateral margins oriented dorsolaterally; anterolateral edges of frontals forming an oblique suture with prefrontals; suture between frontals and parietals curved; ventral edges of vertical laminae of frontals in contact medially, in contact with dorsal projection of parabasisphenoid ventrally. Parietal single, with medial anterodorsally oriented depression, subhexagonal in dorsal view, slightly broader than long, forming posterodorsal margin of orbit, bearing triangular lateral process on each side at level of mid-length, of which the anterior edge contacts postorbital; conspicuous lateral ridges extending from region of contact with postorbitals to slightly anterior to suture with supraoccipital; parietal anteroventrally in contact with posteriormost portion of parasphenoid rostrum, lateroventrally in contact with basisphenoid portion of parabasisphenoid, posterolaterally in contact with anterior margin of prootics and supratemporals, and posteriorly in contact with supraoccipital with slightly curved suture. Postorbitals long, narrow, slightly curved, forming posterolateral margin of orbit; in contact with lateral process of parietal medially and freely extending parietal ventrally, approaching, but not in contact with ectopterygoid. Supraoccipital single, subpentagonal, broader than long, in contact with prootics laterally, and exoccipitals posteriorly; conspicuous medial crest dividing two depressions posteriorly. Exoccipitals irregularly shaped, with medial constriction and two lateral ridges continuous with posterolateral ridges of supraoccipital; in contact with basioccipital ventrally and prootics and supratemporals laterally; fenestra ovalis at suture between prootic and exoccipital; posteriorly, exoccipitals forming dorsal, lateral, and lateroventral border of foramen magnum. Basioccipital subhexagonal to somewhat heartshaped, in contact with parabasisphenoid complex anteriorly, prootics anterolaterally, exoccipitals posterolaterally, and forming ventral border of foramen magnum posteriorly; pronounced anteroventrally oriented medial ridge crosses about half of basioccipital; anterior basioccipital with two short medially oriented oblique ridges, each $50 \%$ length of medial ridge. Prootics ovoid in lateral view, each with two large and two small foramina and uneven surface; overlain by supratemporals dorsally, in contact with parietal dorsally and anteriorly, and parabasisphenoid complex anteroventrally; posteriorly forming anterior margin of fenestra ovalis at suture with exoccipitals. Parasphenoid and basisphenoid fused in ventral view, but separate in dorsal view; basisphenoid subhexagonal in dorsal view with large median cavity; parasphenoid in contact with anteriormost border of basisphenoid and parietal, tapering anteriorly and ending shortly before reaching posterior aspect of vomers, nasals, and septomaxillae with trifurcate margin; anterior portion of parasphenoid rostrum surpassing choanal process of palatine, almost in contact with it ventrally; parasphenoid rostrum with lateral groove on each side along most of its length except for posteriormost $15 \%$; anteromedial portion of basisphenoid with two lateral conspicuous sigmoidal ridges extending 
posterolaterally to suture of basisphenoid with parietal and prootic; small foramen slightly lateral to each sigmoidal ridge, near suture with parietal and prootic; two additional foramina on each side, anterior and posterior to each ridge; posterior part of parasphenoid lateroventrally extended.

Palatomaxillary arch.-Maxillae long, extending from vomerine processes of premaxilla to posterior border of postorbital, in contact with ectopterygoid; arched toward premaxilla, with lateral twist between ectopterygoid and prefrontal, forming the ventral margin of orbit laterally; ventral surface of maxillae with 45 tooth loci; teeth subequal, curved, and rearfacing, increasing in size posteriorly; palatine process situated slightly anterior to center of maxilla, facing medially and in contact with prefrontal dorsally; ectopterygoid process between $37^{\text {th }}$ and $40^{\text {th }}$ tooth, facing medially, tip of process partly overlain by anteromedial process of ectopterygoid; posterior process of maxilla completely overlain by anterolateral process of ectopterygoid. Ectopterygoids axeshaped, with triangular anteromedial process, subrectangular anterolateral process, and rodlike, slightly curved posterior process; ventral surface of posterior half in contact with dorsal surface of lateral portion of pterygoid. Pterygoids elongate, corresponding approximately to half length of skull, ventral surface with 33 tooth loci; teeth subequal, slightly curved, and rearfacing; anterior portion of pterygoid slender, dorsally overlain by posterior toothless portion of palatine up to level of $4^{\text {th }}$ pterygoid tooth; gradually broadening in longitudinal direction from region of contact with ectopterygoid up to level of last tooth, tapering posterolaterally between last tooth and rounded posterior end; pterygoids nearly parallel along tooth line and laterally apart posterior to tooth line; dorsal surface of posterior half with median longitudinal ridge extending from point posterior to contact zone with ectopterygoid to shortly before rounded end. Palatines slender, almost straight, about as long as toothed region of pterygoid, ventral surface with 28 tooth loci; teeth subequal, slightly curved, and rear-facing; anterior portion of palatines in contact with globular portion of vomers medially; long rectangular choanal process dorsomedially directed toward and almost in contact with parasphenoid rostrum and its counterpart anteromedially; short maxillary process situated at level of anterior border of choanal process on lateral surface of palatine, directed posterolaterally, anterior region almost in contact with palatine process of maxilla, dorsal surface in contact with medioventral region of prefrontal; posterior end tapering, flattened, overlaying and in contact with anterior part of pterygoid; short, median, thumb-like process near contact zone with pterygoid.

Suspensorium and mandible.-Supratemporals laminar, elongate; anterior end slightly surpassing suture of prootic and parietal; overlaying and firmly in contact with prootic and lateral part of exoccipital; posterior half, except ultimate end, laterally articulating with quadrate; posterior end free, surpassing exoccipital and quadrate. Quadrate flattened, oblique oriented, and broad dorsally, with straight dorsal end, tapering dorsoventrally; medial portion with short process corresponding to region of contact with columella auris; ventral portion straddling glenoid cavity of retroarticular process of mandible; ventromedial portion approaching but not in contact with pterygoid. Dentaries medially curved anteriorly; dorsal surface with 40 tooth loci; teeth subequal, slightly curved, rear-facing, becoming gradually smaller posteriorly; lateral face convex with mental foramen located at about level of $16^{\text {th }}$ tooth; dentary branching at about level of $24^{\text {th }}$ tooth into long slender dorsal process, which overlays but does not contact compound bone in dorsal view, and shorter broader ventrolateral process, which contacts splenial, angular, and anterior part of medioventral process of compound bone; dorsal process branching at level between $28^{\text {th }}$ and $29^{\text {th }}$ tooth into short medial process and much longer tooth-bearing dorsal process. Splenials elongate, triangular, with foramen below the summit, tapered 

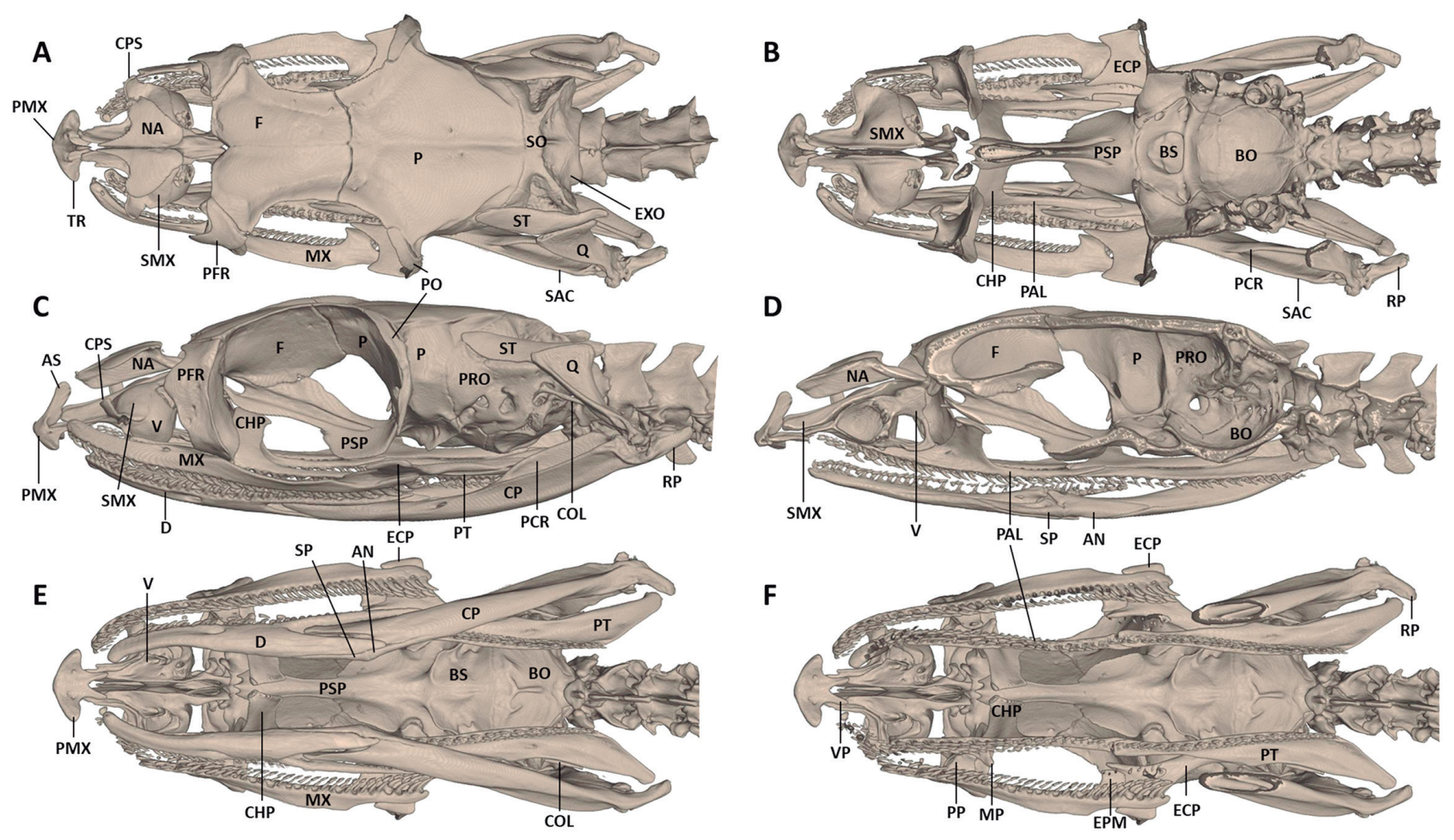

Figure 2. Micro-CT images of the skull of Chironius leucometapus (QCAZ 10977, adult female) in (A, B) dorsal, (C, D) lateral, and $(\mathbf{E}, \mathbf{F})$ ventral views; $\mathrm{B}, \mathrm{D}, \mathrm{F}$ : cutaway views. $\mathrm{AN}=$ angular; $\mathrm{AS}=$ ascending process of premaxilla; $\mathrm{BO}=$ basioccipital; $\mathrm{BS}=$ basisphenoid; $\mathrm{CHP}=$ choanal process of palatine; $\mathrm{COL}=$ columella; $\mathrm{CP}$ = compound bone; $\mathrm{CPS}=$ conchal process of septomaxilla; $\mathrm{D}=$ dentary; $\mathrm{ECP}=$ ectopterygoid; $\mathrm{EPM}=$ ectopterygoid process of maxilla; $\mathrm{EXO}=$ exoccipital; $\mathrm{F}=$ frontal; $\mathrm{MP}=$ maxillary process of palatine; $\mathrm{MX}=$ maxilla; $\mathrm{NA}=$ nasal; $\mathrm{PMX}=$ premaxilla; $\mathrm{PFR}=$ prefrontal; $\mathrm{P}=$ parietal $; \mathrm{PAL}=$ palatine; $\mathrm{PCR}=$ prearticular crest of compound bone; $\mathrm{PO}=$ postorbital; $\mathrm{PP}=$ palatine process of maxilla; $\mathrm{PRO}=$ prootic; $\mathrm{PSP}=$ parasphenoid rostrum; $\mathrm{PT}=$ pterygoid; $\mathrm{Q}=$ quadrate; $\mathrm{RP}=$ retroarticular process of compound bone; $\mathrm{SAC}=$ surangular crest of compound bone; $\mathrm{SMX}=$ septomaxilla; $\mathrm{SO}=$ supraoccipital; $\mathrm{SP}=$ splenial; $\mathrm{ST}=$ supratemporal; $\mathrm{TR}=$ transverse process of premaxilla; $\mathrm{V}=$ vomer; $\mathrm{VP}=$ vomerine process of premaxilla.

anteriorly in region of contact with dentary; posterior part in contact with anterior region of angular.

Angulars elongate, triangular, tapered posteriorly; in contact with compound bone laterally; anterodorsal process approaching but not in contact with medial process of dentary; bearing foramen at suture with splenial. Compound bones elongate, approximately twothirds length of mandible; prearticular crest prominent and visible in lateral view, distinctly higher than surangular crest, the latter hardly visible in medial view; in lateral view, compound bone tapering anteriorly, fitting between dorsal and ventrolateral processes of dentary; dorsally oriented foramen at about level where posterior tip of splenial meets compound bone; retroarticular process relatively long, medially directed.

\section{Hemipenis (FHGO 3570; Figure 4)}

Organ simple, cylindrical, and relatively long (31 mm); when adpressed to the outside of the tail, extending from cloaca to sixth subcaudal scale; sulcus spermaticus single, linear, terminating subapically; proximal half of organ naked basally, covered with spines ( 16-28 spines around) distally; enlarged proximal spines absent; distal 

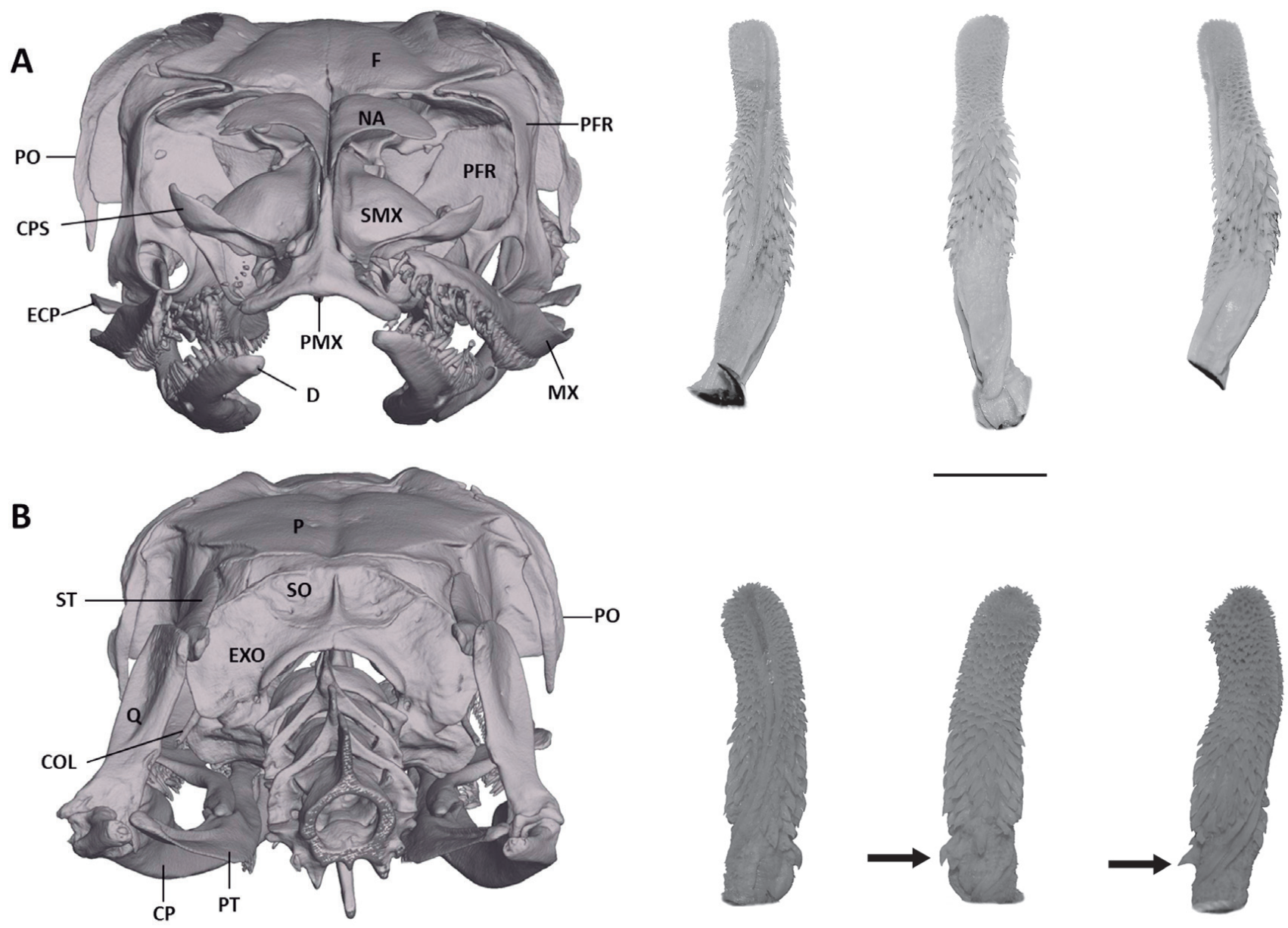

Figure 3. Micro-CT images of the skull of Chironius leucometapus (QCAZ 10977, adult female) in (A) anterior and (B) posterior views. $\mathrm{COL}=$ columella; $\mathrm{CP}=$ compound bone; $\mathrm{CPS}=$ conchal process of septomaxilla; $\mathrm{D}=$ dentary; $\mathrm{ECP}=$ ectopterygoid; $\mathrm{EXO}=$ exoccipital; $\mathrm{F}=$ frontal; $M X=$ maxilla; $N A=$ nasal; $P M X=$ premaxilla; $\mathrm{PFR}=$ prefrontal; $\mathrm{P}=$ parietal; $\mathrm{PO}$ = postorbital; $\mathrm{PT}=$ pterygoid; $\mathrm{Q}=$ quadrate; SMX = septomaxilla; $\mathrm{SO}=$ supraoccipital; ST = supratemporal.

half of organ calyculate, with papillate fringes proximally and uniform fringes distally; calyculate pockets decrease in size distally.

\section{Color Patterns}

Color in preservative (QCAZ 10977; Figure 5).-Dorsal background uniformly grayish blue, darker middorsally; ventral body and tail pale

Figure 4. Left hemipenis of Chironius leucometapus (top, FHGO 3570) and C. fuscus (bottom, FHGO 11478) in sulcate (left), asulcate (middle), and lateral (right) views. Basal spine in $C$. fuscus is indicated by black arrows. Scale bar $=10 \mathrm{~mm}$. Photographs by Jorge Valencia.

blue, anterior ventrals cream medially, becoming progressively pale blue anterior to midbody; all ventrals with dark margins; rostral, internasals, anterior half of nasals, and prefrontals light brown, frontal medium brown; supraoculars and parietals light brown medially, becoming blue laterally; parietals with medial brown blotch, same shade as frontal; temporal, postoculars, preocular, loreal, posterior half of nasal and upper part of supralabials grayish blue; lower part of supralabials cream; mental, infralabials, genials, and gulars cream. 
Color in life.-QCAZ 9955; juvenile, data from two low-quality photographs: Dorsal background dark green, with darker green transverse bands 3 or 4 scales wide extending from ventral 40 to tip of tail; venter pale green; snout rusty brown; head dark green posteriorly; iris bronze with dark brown or black reticulations; tongue black. CORBIDI 0620; juvenile (Figure 6A): dorsal background mossy green, with two black paravertebral stripes and narrow yellow transverse bands from midbody to vent; skin between scales sky blue on anterior half of body and black on posterior half; rostral, first pair of supralabials, internasals, prefrontals, nasals, frontal, and anterior half of each supraocular coppery orange; head light green laterally, temporals mossy green; ventral surface pale yellowish green; iris dark brown with gold pigmentation ventrally and around pupil. Subadult male specimen CORBIDI 19374 (Figure 6B) differs from CORBIDI 0620 in lacking the narrow yellow transverse bands along the dorsum. CORBIDI 01256; adult female (Figure 6C): similar in coloration to juveniles; narrow yellow bands from midbody to vent; throat and first quarter of venter yellow, remainder of venter including tail pale green.

\section{Distribution and Natural History}

Chironius leucometapus occurs at elevations between 500 and $3500 \mathrm{~m}$ a.s.l. (mean $966.2 \mathrm{~m}$ a.s.l.) along the Amazonian slopes of the Andes (Figure 1) of Ecuador (Sucumbíos, Napo, Pastaza, and Morona Santiago provinces) and Peru (Huánuco, Junín, Pasco, and San Martín departments). Its known distribution lies within the South Brazilian, Boreal Brazilian and Pacific dominions of the Brazilian subregion (Morrone 2014).

Based on available data from Peru (Huánuco and San Martín departments), it appears that egg deposition and hatching in Chironius leucometapus occurs between November and

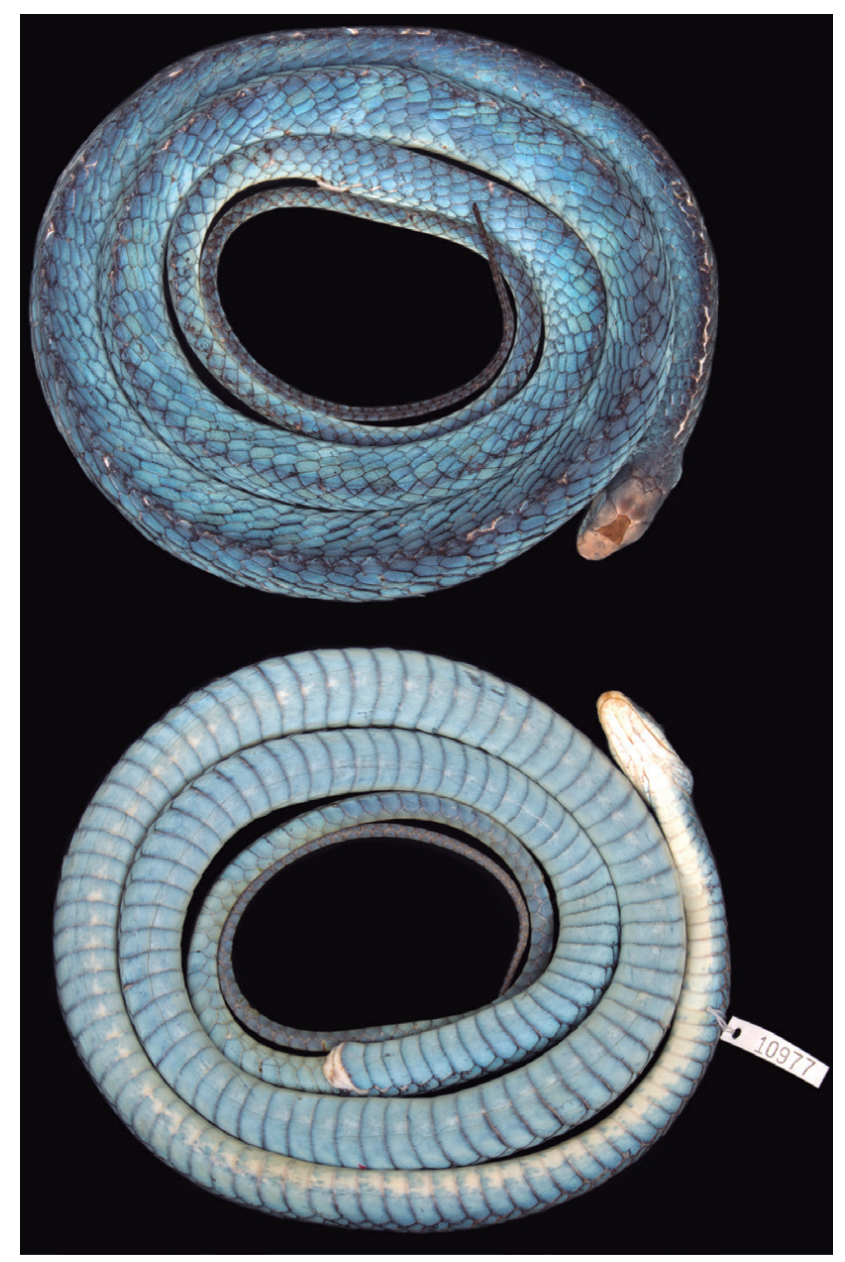

Figure 5. Preserved specimen of Chironius leucometapus from Cotundo, 12 km NW Antisana Ecological Reserve, Napo, Ecuador (QCAZ 10977, adult female, total length $=137.3 \mathrm{~cm}$ ) in dorsal (top) and ventral (bottom) views. Photographs by D. Paucar.

January, which corresponds to the rainy season. Female specimen CORBIDI 01256 (SVL 794 $\mathrm{mm}$ ), collected in December 2003, had six fully developed eggs ranging from $33.47 \mathrm{~mm}$ to 49.45 $\mathrm{mm}$ in length and $13.72 \mathrm{~mm}$ to $15.17 \mathrm{~mm}$ in width. CORBIDI 16478 (SVL $881 \mathrm{~mm}$ ), collected in November 2015, had four fully developed eggs ranging from 43.12-53.09 mm in length and $11.48-13.1 \mathrm{~mm}$ in width. Juvenile specimens CORBIDI 0620 (SVL $282 \mathrm{~mm}$ ) and CORBIDI 15562 (SVL $267 \mathrm{~mm}$ ) were collected in January and November, respectively. 


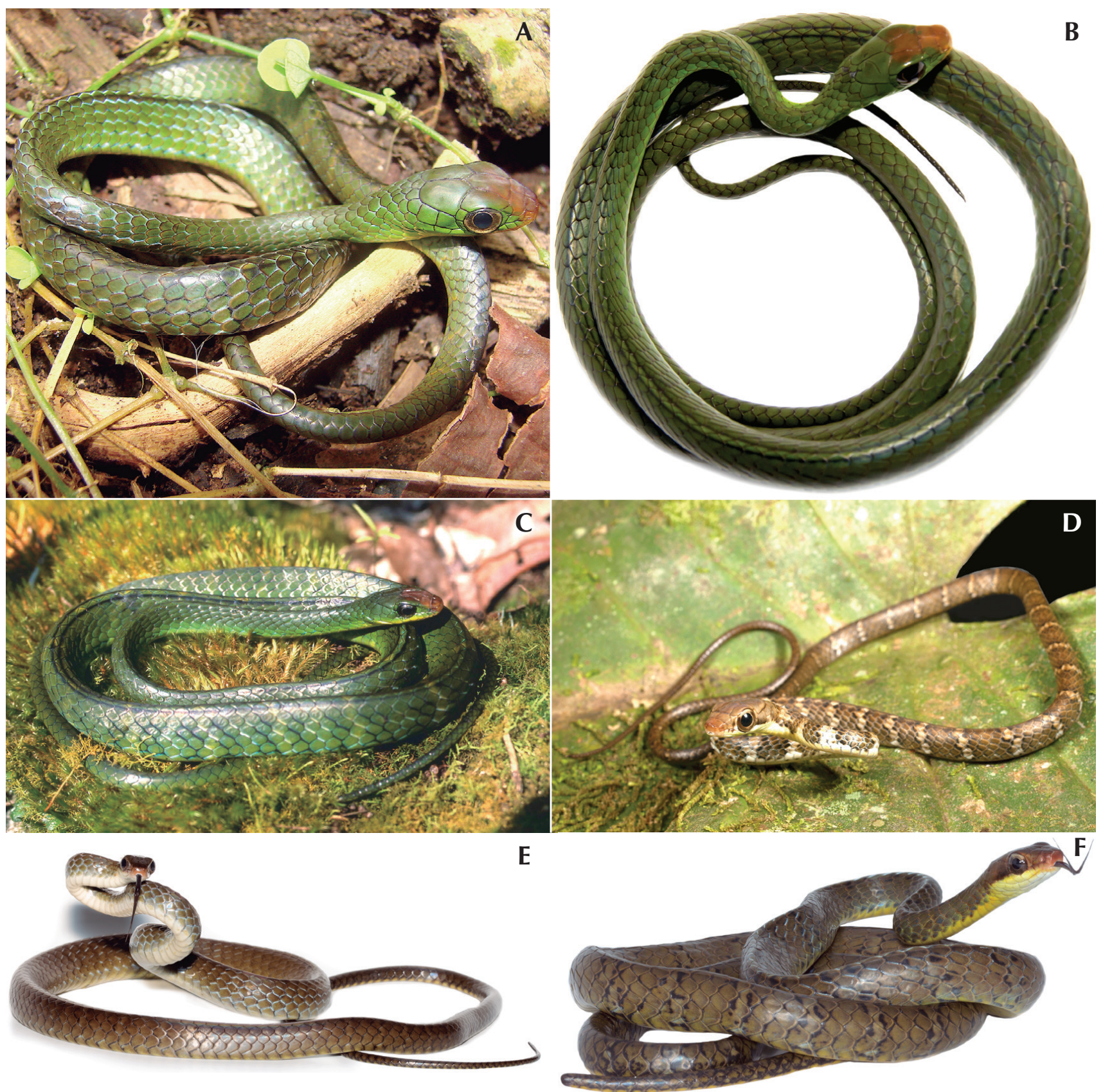

Figure 6. Living Chironius leucometapus (A, B, C) and C. fuscus (D, E, F). (A) Juvenile, CORBIDI 0620 (La Cueva, San Martín, Peru). (B) Subadult male, CORBIDI 19374 (Sharco, Huánuco, Peru). (C) Adult female, CORBIDI 01256 (El Dorado, near Río Blanco, San Martín, Peru). (D) Juvenile, QCAZ 8372 (Agip Oil Block 10, Pastaza, Ecuador). (E) Adult QCAZ 13821 (Bombuscaro, Zamora-Chinchipe, Ecuador). (F) Adult QCAZ 5249 (Yasuni National Park, Orellana, Ecuador).

\section{Discussion}

Chironius leucometapus has been considered to be a rare snake species because of its restricted range (Dixon et al. 1993). More than 25 years after its description, we show that this species is widespread along the Amazonian slopes of the Central (Peru) and Northern (Ecuador) Andes. 
Our records extend the known distribution of this species 1200 linear $\mathrm{km}$ north of the type locality (Figure 1). Torres-Carvajal et al. (2019) referred to specimen QCAZ 9955 as an undescribed species sister to $C$. leucometapus based on lower number of ventral scales relative to C. leucometapus (OTC, personal comment). Additional specimens examined here verify that the number of ventral scales differs between Ecuadorian and Peruvian specimens of $C$. leucometapus (Table 1). Strong similarities in other morphological characters and coloration, as well as relatively small genetic distance, indicate that the number of ventrals is only an interpopulational difference in C. leucometapus.

We present the first detailed description of the skull of species of Chironius based on highquality CT-scan images (Figures 2, 3), thereby contributing to the general knowledge of the skull of colubrid snakes. The skulls of many species of Chironius have been examined to score phylogenetic characters (Klaczko et al. 2014), but the skull anatomy of only two species [C. Alavolineatus (Jan, 1863) and C. brazili Hamdan and Fernandes, 2015] has been described in detail based on direct observation of dry skulls (Hamdan and Fernandes 2015). Even though these species are phylogenetically distant from $C$. leucometapus, the skulls of all three species closely resemble one another.

Dixon et al. (1993) coined the name leucometapus from the Greek words leuco (white) and metapon (forehead) in reference to the white or dirty yellow foreheads of preserved specimens that he examined. In life, the forehead of this species varies from rusty brown to coppery orange (Figure 6). Therefore, we propose "Rusty-fronted Sipo Snakes" and "Sipos de Hocico Rojizo" as standard English and Spanish names, respectively. The first photographs of everted hemipenes of both $C$. leucometapus and its sister species $C$. fuscus (Figure 4) presented here confirm that the hemipenis of $C$. leucometapus differs from the hemipenis of $C$. fuscus in lacking enlarged spines on the proximal end of the spinous portion of the hemipenial body (Dixon et al. 1993).
Although some widely distributed Neotropical reptile species are cryptic species complexes (Nunes et al. 2012, Werneck et al. 2012, Carvalho et al. 2013, Domingos et al. 2014, Murphy et al. 2016), others, such as Chironius scurrulus, are single species with broad distributions (Pinto et al. 2019, TorresCarvajal et al. 2019). This study provides further evidence that not all widely distributed Neotropical reptile species are species complexes.

\section{Acknowledgments}

Special thanks to Luke Mahler, University of Toronto, for providing access to the high resolution micro-CT scanner and Jhael Ortega for scanning the skull presented here. We also thank A. Almendáriz (EPN), K. Garzón-Tello and M. E. Barragán (FHGO), and M. Muñoz-Yánez (DHMECN) for providing access to specimens. This manuscript benefited from excellent comments by two anonymous reviewers and an associate editor. Specimens from Ecuador examined in this paper were collected under collection permits 008-09 IC-FAU-DNB/MA to PUCE and 009-ICDNBAPVS/MA to FHGO, issued by Ministerio del Ambiente, República del Ecuador, and specimens from Peru under permits 110-2007-I NRENA-IFFS-DCB，118-2007- INRENA-IFFSDCB, and 019-2015- SERFOR-DGGSPFFS. This work was supported by the Secretaría de Educación Superior, Ciencia, Tecnología e Innovación (SENESCYT) under the "Arca de Noé" Initiative (PIs: S.R. Ron and O. Torres-Carvajal).

\section{References}

Bailey, J. R. 1955. The snakes of the genus Chironius in southeastern South America. Occasional Papers of the Museum of Zoology, University of Michigan 571: 1-21.

Bullock, R. E. and W. W. Tanner. 1966. A comparative osteological study of two species of colubridae (Pituophis and Thamnophis). Brigham Young University Science Bulletin, Biological Series 8: 1-29.

Carvalho, A. L. G., M. R. Britto, and D. S. Fernandes. 2013. Biogeography of the lizard genus Tropidurus Wied- 
Neuwied, 1825 (Squamata: Tropiduridae): distribution, endemism, and area relationships in South America. PLOS ONE 8: e59736.

Cundall, D. and F. J. Irish. 2008. The snake skull. Pp. 349692 in C. Gans, A. S. Gaunt, and K. Adler (eds.), Biology of the Reptilia. Volume 20. Morphology H: The Skull of Lepidosauria. Ithaca. Society for the Study of Amphibians and Reptiles.

Dixon, J. R., J. A. Wiest, and J. M. Cei. 1993. Revision of the Neotropical Snake Genus Chironius Fitzinger (Serpentes, Colubridae). Monografie XIII. Torino. Museo Regionale di Scienze Naturali. 279 pp.

Domingos, F. M. C. B., R. J. Bosque, J. Cassimiro, G. R. Colli, M. T. Rodrigues, M. G. Santos, and L. B. Beheregaray. 2014. Out of the deep: cryptic speciation in a Neotropical gecko (Squamata, Phyllodactylidae) revealed by species delimitation methods. Molecular Phylogenetics and Evolution 80: 113-124.

Erwin, T. L., M. C. Pimienta, O. E. Murillo, and V. Aschero. 2004. Mapping patterns of $\mathrm{\square}$-diversity for beetles across the western Amazon basin: a preliminary case for improving inventory methods ans conservation strategies. Proceedings of the California Academy of Sciences 56: 72-85.

Fernandes, D. S. and B. Hamdan. 2014. A new species of Chironius Fitzinger, 1826 from the state of Bahia, northeastern Brazil (Serpentes: Colubridae). Zootaxa 3881: 563-575.

Figueroa, A., A. D. McKelvy, L. L. Grismer, C. D. Bell, and S. P. Lailvaux. 2016. A species-level phylogeny of extant snakes with description of a new colubrid subfamily and genus. PLOS ONE 11: e0161070.

Hamdan, B. and D. S. Fernandes. 2015. Taxonomic revision of Chironius flavolineatus (Jan, 1863) with description of a new species (Serpentes: Colubridae). Zootaxa 4012: 97-119.

Hamdan, B., A. G. Pereira, L. Loss-Oliveira, D. Rödder, and C. G. Schrago. 2017. Evolutionary analysis of Chironius snakes unveils cryptic diversity and provides clues to diversification in the Neotropics. Molecular Phylogenetics and Evolution 116: 108-119.

Hollis, J. L. 2006. Phylogenetics of the genus Chironius Fitzinger, 1826 (Serpentes, Colubridae) based on morphology. Herpetologica 62: 435-453.

Killeen, T. J., M. Douglas, T. Consiglio, P. M. Jørgensen, and J. Mejia. 2007. Dry spots and wet spots in the Andean hotspot. Journal of Biogeography 34: 13571373 .
Klaczko, J., G. G. Montingelli, and H. Zaher. 2014. A combined morphological and molecular phylogeny of the genus Chironius Fitzinger, 1826(Serpentes: Colubridae). Zoological Journal of the Linnean Society 171: 656667.

Manzani, P. R. and A. S. Abe. 1988. Sobre dois novos métodos de preparo do hemipênis de serpentes. Memorias do Instituto Butantan 50: 15-20.

Morrone, J. J. 2014. Biogeographical regionalisation of the Neotropical region. Zootaxa 3782: 1-110.

Murphy, J. C., M. J. Jowers, R. M. Lehtinen, S. P. Charles, G. R. Colli, A. K. Peres Jr., C. R. Hendry, and R. A. Pyron. 2016. Cryptic, sympatric diversity in Tegu lizards of the Tupinambis teguixin Group (Squamata, Sauria, Teiidae) and the description of three new species. PLoS ONE 11: e0158542.

Nunes, P. M. S., A. Fouquet, F. F. Curcio, P. J. R. Kok, and M. T. Rodrigues. 2012. Cryptic species in Iphisa elegans Gray, 1851 (Squamata: Gymnophthalmidae) revealed by hemipenial morphology and molecular data. Zoological Journal of the Linnean Society 166: 361376.

Pesantes, O. S. 1994. A method for preparing the hemipenis of preserved snakes. Journal of Herpetology 28: 93-95.

Pinto, B. J., G. R. Colli, T. E. Higham, A. P. Russell, D. P. Scantlebury, L. J. Vitt, and T. Gamble. 2019. Population genetic structure and species delimitation of a widespread, Neotropical dwarf gecko. Molecular Phylogenetics and Evolution 133: 54-66.

Pyron, R. A., F. T. Burbrink, and J. J. Wiens. 2013. A phylogeny and revised classification of Squamata, including 4161 species of lizards and snakes. BMC Evolutionary Biology 13: 1-53.

Roll, U., A. Feldman, M. Novosolov, A. Allison, A. M. Bauer, R. Bernard, M. Böhm, F. Castro-Herrera, L. Chirio, B. Collen, G. R. Colli, L. Dabool, I. Das, T. M. Doan, L. L. Grismer, M. Hoogmoed, Y. Itescu, F. Kraus, M. LeBreton, A. Lewin, M. Martins, E. Maza, D. Meirte, Z. T. Nagy, C. C. Nogueira, O. S. G. Pauwels, D. Pincheira-Donoso, G. D. Powney, R. Sindaco, O. J. S. Tallowin, O. Torres-Carvajal, J.-F. Trape, E. Vidan, P. Uetz, P. Wagner, Y. Wang, C. D. L. Orme, R. Grenyer, and S. Meiri. 2017. The global distribution of tetrapods reveals a need for targeted reptile conservation. Nature Ecology \& Evolution 1: 1677-1682.

Swofford, D. L. 2002. PAUP* Phylogenetic Analysis Using Parsimony (*and Other Methods), Version 4.0b10. Sunderland. Sinauer Associates. 
Ter Steege, H., N. Pitman, D. Sabatier, H. Castellanos, P. van der Hout, D. C. Daly, M. Silveira, O. Phillips, R. Vasquez, T. van Andel, J. Duivenvoorden, A. A. Oliveira, R. Ek, R. Lilwah, R. Thomas, J. van Essen, C. Baider, P. Maas, S. Mori, J. Terborgh, P. N. Vargas, H. Mogollón, and W. Morawetz. 2003. A spatial model of tree $\alpha$-diversity and tree density for the Amazon region. Biodiversity and Conservation 12: 2255-2277.

Torres-Carvajal, O., L. Y. Echevarría, S. E. Lobos, P. J. Venegas, and P. J. R. Kok. 2019. Phylogeny, diversity and biogeography of Neotropical sipo snakes (Serpentes: Colubrinae: Chironius). Molecular Phylogenetics and Evolution 130: 315-329.

Werneck, F. P., T. Gamble, G. R. Colli, M. T. Rodrigues, and J. J. W. Sites. 2012. Deep diversification and longterm persistence in the South American 'Dry
Diagonal': integrating continent-wide phylogeography and distribution modeling of geckos. Evolution 66: 3014-3034.

Zaher, H. 1999. Hemipenial morphology of the South American xenodontine snakes with a proposal for a monophyletic Xenodontinae and a reappraisal of colubroid hemipenes. Bulletin of the American Museum of Natural History 240: 1-168.

Zaher, H., R. W. Murphy, J. C. Arredondo, R. Graboski, P. R. Machado-Filho, K. Mahlow, G. G. Montingelli, A. B. Quadros, N. L. Orlov, M. Wilkinson, Y.-P. Zhang, and F. G. Grazziotin. 2019. Large-scale molecular phylogeny, morphology, divergence-time estimation, and the fossil record of advanced caenophidian snakes (Squamata: Serpentes). PLoS ONE 14: e0217959.

Editor: Ross D. MacCulloch

Appendix I. Specimens examined. $s=$ skull, $h=$ hemipenis.

Chironius leucometapus: ECUADOR. Morona SAntiago: Concesión Minera Kinross-Aurelian, 0344'56.70" S, 78³2'35.38" W, 1586 m a.s.1., DHMECN 10207; Taisha, Mutintsa, 0346' S, 78²43' W, FHGO 1147, 3570 (h). NAPO: Cotundo, 12 km NW Reserva Ecológica Antisana, 0042'54" S, 7748'46.8" W, 1400 m a.s.l., QCAZ 10977 (s). PASTAZA: Ingaru community, Reserva Privada Ankaku, 01¹6'03.504" S, 7802'52.692" W, 1180 m a.s.1., QCAZ 9955; Bosque Protector Pablo López de

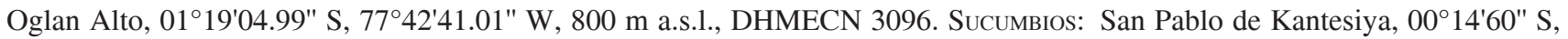
76²4'59.99" W, 300 m a.s.1., DHMECN 0087. No Further Locality Data: Piso tropical oriental, EPN 9552; Oriente, EPN13223. PERU. HuÁnuCo: Cruz Blanca, Parque Nacional Tingo Maria, 09²0'18.39" S, 7600'7.4" W, 1095 m a.sl.., CORBIDI 15562; Pampamarca-Embalse, 0942'13.85" S, 7548'08.06" W, $1167 \mathrm{~m}$ a.s.l., CORBIDI 16478; Rupa rupa, 0942'33.85" S, 7549'15.15" W, 1064 m a.s.1., CORBIDI 16386; Sharco 09³5'53.73" S, 8154'06.58" W, 1652 m a.s.1., CORBIDI 19374. PASco: Puesto de Control Huampal, $1050 \mathrm{~m}$ a.s.1., CORBIDI 7260. SAn Martin: Paitoja, 06² $21^{\prime} 10.15^{\prime \prime}$ S, 7703'52.22" W, 1737 m a.s.l., CORBIDI 1276; El Dorado, near Río Blanco, 0646'00" S, 77³2'42" W, 1580 m a.s.1., CORBIDI 01256; La Cueva, 06²45'59.9754" S, 77³2'42" W, 1500 m a.s.l., CORBIDI 0620. 